\title{
(OP General Medicine \\ STUDY OF PLEURAL FLUID TO SERUM CHOLINESTERASE RATIO TO DIFFERENTIATE BETWEEN TRANSUDATE AND EXUDATE AND ITS CORRELATION WITH LIGHT'S CRITERIA
}

\section{Dr.Manohar MR*}

\section{Dr.Deepti Shetty}

Vikram VM
Assistant Professor, Department of Medicine, AIMS, BG Nagar. *Corresponding Author

Senior Resident, Department of Paediatrics, AIMS, BG Nagar.

management of pleural effusion is its differentiation into transudates and exudates. Light's criteria is the most widely used parameter to differentiate pleural effusions but studies have shown that Light's criteria misclassifies a significant amount of cases. Methods: Study included 125 patients who had pleural effusion who met the inclusion and exclusion criteria. Duration of the study was 12 months. Results: Accordingly the mean value of this ratio was $0.10 \pm 0.05$ in the transudates group and $0.39 \pm 0.14$ in the exudates group. This difference was found to be statistically significant ( $\mathrm{p}$-value $<0.001)$. This ratio misclassified 5 cases. Among them $2(3.2 \%)$ were transudates that were misdiagnosed as exudates and $3(4.8 \%)$ were exudates that were misdiagnosed as transudates.In this study Light's criteria misclassified 13 cases in total with a sensitivity of $91.9 \%$ and a specificity of $87.3 \%$. Conclusions: Light's criteria has a good sensitivity and specificity but P/S ChE was the most efficient parameter in differentiating between transudates and exudates in this study.

\section{KEYWORDS : Pleural Effusion, Pseudocholinesterase, Light's Criteria}

\section{INTRODUCTION:}

Pleural effusion is the abnormal accumulation of fluid in the pleural space. A pleural effusion is always abnormal and indicates the presence of an underlying disease. ${ }^{1}$ The first step in management of pleural effusion is to classify pleural fluid into a transudate or exudate even if this differentiation does not contribute to the etiological diagnosis. Transudative pleural effusion is caused by limited number of diseases. However exudative effusions might require extensive diagnostic investigations. For this purpose many criteria have been used but they weren't satisfactory.

In 1972, Light et $\mathrm{al}^{2}$, developed a set of criteria for the diagnostic separation of pleural fluids into transudates and exudates. These included- a. pleural fluid to serum total protein ratio $>0.5$, b. pleural fluid to serum LDH ratio $>0.6$ and c. Pleural fluid LDH more than twothirds the normal upper limit for serum. However these criteria misidentify $\sim 25 \%$ of transudates as exudates. ${ }^{3}$ Many biochemical parameters like pleural fluid cholesterol, bilirubin, albumin, alkaline phosphatase, adenosine deaminase $e^{4.7}$, malondialdehyde (MDA) and their ratio with serum values have been used to differentiate the type of pleural effusion.

In 1990, in a study of 46 patients with pleural effusions, Meisel et al evaluated the usefulness of the pleural fluid to serum bilirubin concentration ratio. With this criterion 3 of 23 transudates and 6 of 23 exudates were misclassified. This result was not superior to that obtained with criteria of Light et al. ${ }^{8}$

Paramothayan et $\mathrm{al}^{9}$ conducted a study on 54 patients in 2002 and found that pleural fluid $\mathrm{LDH}$ and fluid to serum protein ratio measurements were equally good at differentiating between exudates and transudates, with a sensitivity of $90 \%$, a specificity of $79 \%$, a positive predictive value (PPV) of $84 \%$, and a negative predictive value (NPV) of $86 \%$. A combination of these parameters improved sensitivity to $100 \%$ and NPV to $100 \%$, but lowered the specificity to $71 \%$ and PPV to $81 \%$. This combination achieved a higher efficiency than Light's criteria. However they were not proved to be effective diagnostic tests. And Light's criteria misidentify $\sim 25 \%$ of transudates as exudates. ${ }^{3}$ So there is a need to identify a parameter which is better than the present tests for differentiation.

In 1978, Cabrer et $\mathrm{al}^{10}$ conducted a study on pseudocholinesterase activity in pleural effusions of diverse aetiologies and concluded that there exists difference in the activity of pseudocholinesterase among different types of pleural effusions and it was possible to differentiate them into transudates and exudates with pseudocholinesterase levels.

In 1996, Garcia-Pachon et al conducted a study on 153 patients and Light's criteria, the pleural fluid cholesterol level, the pleural fluid to serum cholesterol ratio, the pleural fluid cholinesterase level, and the pleural fluid to serum cholinesterase ratio were applied. The percentage of effusions misclassified by each parameter was as follows: Light's criteria, 7.8\%; pleural fluid cholesterol, 7.8\%; pleural fluid to serum cholesterol ratio, $6.5 \%$; pleural fluid cholinesterase, $8.5 \%$; and pleural fluid to serum cholinesterase ratio was just $1.3 \%$ making it the most accurate criterion."

A study was conducted on 80 patients by Ozer F et al in 2003 and it was found that the difference between the mean pleural fluid pseudocholinesterase (PChE) levels of transudates and exudates was statistically significant $(p<0.001)$. Similar significance was also obtained in the mean pleural fluid/serum pseudocholinesterase ratios between transudates and exudates $(p<0.001)$. In determination of exudative fluids, both sensitivity and specificity of the $\mathrm{PChE}$ level was $100 \%$. Sensitivity and specificity of the pleural fluid/serum pseudocholinesterase ratio of 0.24 were 90 and $87 \%$, respectively. ${ }^{12}$

\section{METHODOLOGY:}

Patients participating in the study were explained about the procedure, technique and complications of pleural fluid aspiration. Pleural fluid aspiration was performed under strict aseptic precautions after analysing the fluid levels by percussion and chest $\mathrm{x}$-rays. In few of the cases, ultrasonography-guided pleural fluid aspiration was performed. Pleural fluid analysis with protein, $\mathrm{LDH}$ and $\mathrm{ChE}$ estimation along with serum protein, $\mathrm{LDH}$ and $\mathrm{ChE}$ estimation were done and an analysis of the results obtained was done. Protein levels were estimated in serum and pleural fluid by Biuret method. LDH levels were estimated using the kinetic UV test for quantitative determination of LDH by measuring the decrease in absorbance of NADH at $340 \mathrm{~nm}$. Cholinesterase levels were measured using the kinetic colorimetric method based on Ellman reaction using the Beckman Coulter Cholinesterase kit.

\section{INCLUSION CRITERIA-}

- Patients with Age $>18$ yrs

- Presence of pleural effusion proved by clinical/ radiological examination.

- Patient willing to give an informed consent.

\section{EXCLUSION CRITERIA-}

- Patients having pleural effusion with suspected multiple etiologies.

- Patients having hepatic diseases.

- Patients using any of the following drugs - OCPs, anti-cancer drugs, MAO inhibitors, neostigmine, chlorpromazine.

- Pregnant patients

- Patients with OP compound poisoning.

Patients were divided into two groups

- Group I consisted of 62 patients with transudative effusions and 
- Group II consisted of 63 patients with exudative pleural effusion

\section{STATISTICALANALYSIS:}

Data were entered in MS Excel and analysed in SPSS V22. Descriptive statistics for qualitative data was represented with percentages. Logistic regression was applied to find cut-off values.

The usefulness of the biochemical parameters was assessed using the Bayesian method in terms of sensitivity, specificity, positive predictive value and negative predictive value. Results on continuous measurements are presented on Mean SD (Min- Max) and results on categorical measurements are presented in Number $(\%)$.

Area under the curve and $95 \%$ confidence intervals were calculated. $p$ value of less than 0.05 was considered statistically significant.

\section{RESULTS:}

The mean value of serum protein among transudates group and exudates group were $5.96 \pm$

$0.77 \mathrm{~g} / \mathrm{dL}$ and $6.43 \pm 0.89 \mathrm{~g} / \mathrm{dL}$ respectively. And the mean pleural fluid protein levels were

$1.24 \pm 0.62 \mathrm{~g} / \mathrm{dL}$ and $3.37 \pm 0.79 \mathrm{~g} / \mathrm{dL}$ respectively. This ratio was found to be statistically

significant in this study (p-value $<0.05$ )

Table-1: results of pleural fluid to serum protein relation

\begin{tabular}{|c|c|c|}
\hline \multirow{2}{*}{ Transudate } & \multicolumn{2}{|c|}{ Observed } \\
\cline { 2 - 3 } & Transudate & Exudate \\
\cline { 2 - 3 } & 56 & 7 \\
\hline \multirow{2}{*}{ Exudate } & $\mathbf{9 0 . 3 \%}$ & $11.1 \%$ \\
\cline { 2 - 3 } & 6 & 56 \\
\hline \multirow{2}{*}{ Total } & $9.7 \%$ & $\mathbf{8 8 . 9 \%}$ \\
\cline { 2 - 3 } & 62 & 63 \\
\hline
\end{tabular}

The mean value of serum cholinesterase observed in this study was $8288.39 \pm 2980.76 \mathrm{U} / \mathrm{L}$ in transudates group and $9167.89 \pm 3000.46$ $\mathrm{U} / \mathrm{L}$ among the exudates group. The cut off value for pleural fluid to serum cholinesterase ratio was taken as 0.24 according to the study conducted by Gowdaiah PK et al. ${ }^{15}$ Accordingly the mean value of this ratio was $0.10 \pm 0.05$ in the transudates group and $0.39 \pm 0.14$ in the exudates group. This difference was found to be statistically significant ( $\mathrm{p}$-value $<0.001$ ). This criteria misidentified 5 cases in total. Among them $2(3.2 \%)$ were transudates that were misdiagnosed as exudates and $3(4.8 \%)$ were exudates that were misdiagnosed as transudates.

Table-2: Pleural fluid to serum cholinesterase ratio

\begin{tabular}{|c|c|c|}
\hline & \multicolumn{2}{|c|}{ Observed } \\
\hline & Transudate & Exudate \\
\hline Transudate & 56 & 7 \\
\hline & $\mathbf{9 0 . 3 \%}$ & $11.1 \%$ \\
\hline Exudate & 6 & 56 \\
\hline & $9.7 \%$ & $\mathbf{8 8 . 9} \%$ \\
\hline Total & 62 & 63 \\
\hline & $100.0 \%$ & $100.0 \%$ \\
\hline
\end{tabular}

Table-3: Comparison of all the parameters

\begin{tabular}{|c|c|c|c|c|c|}
\hline Variable & Sensitivity & Specificity & PPV & NPV & $\begin{array}{c}\text { Overall } \\
\text { Accuracy }\end{array}$ \\
\hline $\begin{array}{c}\text { Pleural Fluid } \\
\text { Protein (PFP) }\end{array}$ & $91.9 \%$ & $85.7 \%$ & $86.4 \%$ & $91.5 \%$ & $88.8 \%$ \\
\hline $\begin{array}{c}\text { PFP / Serum } \\
\text { Protein }\end{array}$ & $90.3 \%$ & $88.9 \%$ & $88.9 \%$ & $90.3 \%$ & $89.6 \%$ \\
\hline $\begin{array}{c}\text { Pleural Fluid LDH } \\
\text { (PF LDL) }\end{array}$ & $93.5 \%$ & $85.7 \%$ & $86.6 \%$ & $93.1 \%$ & $89.6 \%$ \\
\hline $\begin{array}{c}\text { PF LDH / Serum } \\
\text { LDH }\end{array}$ & $91.9 \%$ & $82.5 \%$ & $83.8 \%$ & $91.2 \%$ & $87.2 \%$ \\
\hline $\begin{array}{c}\text { Pleural Fluid } \\
\text { Choliesterase } \\
\text { (PFC) }\end{array}$ & $93.5 \%$ & $92.1 \%$ & $92.1 \%$ & $93.5 \%$ & $92.8 \%$ \\
\hline $\begin{array}{c}\text { PFC / Serum } \\
\text { Cholinesterase }\end{array}$ & $\mathbf{9 6 . 8 \%}$ & $\mathbf{9 5 . 2 \%}$ & $\mathbf{9 5 . 2 \%}$ & $\mathbf{9 6 . 8 \%}$ & $\mathbf{9 6 . 0 \%}$ \\
\hline Light's Criteria & $91.9 \%$ & $87.3 \%$ & $87.7 \%$ & $91.7 \%$ & $89.6 \%$ \\
\hline
\end{tabular}

Table-4: Area under the curve on basis of accuracy
\begin{tabular}{|c|c|c|c|c|c|}
\hline \multicolumn{5}{|c|}{ Area Under the Curve } \\
\hline Test Result Variable(s) & Area & SE & P-value & $\begin{array}{c}95 \% \text { Confidence } \\
\text { Interval }\end{array}$ \\
\cline { 3 - 7 } & & & $\begin{array}{c}\text { Lower } \\
\text { Bound }\end{array}$ & $\begin{array}{c}\text { Upper } \\
\text { Bound }\end{array}$ \\
\hline PFP / Serum Protein & 0.957 & 0.018 & $<0.001$ & 0.921 & 0.993 \\
\hline Pleural Fluid LDH (PF LDH) & 0.940 & 0.022 & $<0.001$ & 0.897 & 0.983 \\
\hline PF LDH / Serum LDH & 0.903 & 0.030 & $<0.001$ & 0.845 & 0.962 \\
\hline $\begin{array}{c}\text { Pleural Fluid Choliesterase } \\
\text { (PFC) }\end{array}$ & 0.971 & 0.013 & $<0.001$ & 0.945 & 0.997 \\
\hline $\begin{array}{c}\text { PFC / Serum } \\
\text { Cholinesterase }\end{array}$ & $\mathbf{0 . 9 8 6}$ & $\mathbf{0 . 0 1 0}$ & $<\mathbf{0 . 0 0 1}$ & $\mathbf{0 . 9 6 7}$ & $\mathbf{1 . 0 0 0}$ \\
\hline Light's Criteria & 0.896 & 0.032 & $<0.001$ & 0.834 & 0.958 \\
\hline
\end{tabular}

DISCUSSION:

Table-5: Efficacy of pleural fluid to serum cholinesterase ratio in various studies

\begin{tabular}{|c|c|c|}
\hline Study & Sensitivity & Specificity \\
\hline Garcia-Pachon et al ${ }^{11}$ & $100 \%$ & $94.5 \%$ \\
\hline Sharma et $\mathbf{a l}^{13}$ & $98.75 \%$ & $96.67 \%$ \\
\hline Gowdaiah PK et al $^{14}$ & $100 \%$ & $96.7 \%$ \\
\hline Present study & $96.8 \%$ & $95.2 \%$ \\
\hline
\end{tabular}

Cholinesterase is synthesized in the liver and its levels can be influenced by different disorders like acute hepatitis, cirrhosis, acute infections, pulmonary embolism, chronic renal disease, and after surgical procedures. Hence, the ratio of pleural fluid to serum cholinesterase is a better parameter than the absolute value of cholinesterase in the pleural fluid.

The pleural fluid to serum ratio of LDH misclassified the maximum number of cases in this study. In the study done by Sharma et $\mathrm{al}^{13}$ and Gowdaiah PK et $\mathrm{al}^{14}$ the ratio of pleural fluid to serum LDH was not found to have a statistically significant difference between transudates and exudates.

The pleural fluid protein levels misclassified 13 cases in this study. In the study done by Gowdaiah PK et al ${ }^{14}$ it misdiagnosed 6 cases and in the study by Sharma et $\mathrm{al}^{13}$, the same parameter misclassified the maximum number of cases.

Pleural effusions are classically divided into transudates and exudates. This is first step in the management of effusions. A transudate occurs when the mechanical factors influencing the formation or reabsorption of pleural fluid are altered. An exudate results from inflammation or other diseases of the pleural surface.

Exudative pleural effusions are a common diagnostic problem in clinical practice, as the list of causes is quite exhaustive although sometimes they can be inferred from the clinical picture. ${ }^{19}$ If an exudative effusion is present, further diagnostic procedures are imperative, such as cytopathology, pleural biopsy and sometimes even thoracotomy to achieve definitive diagnosis. The etiological distribution of pleural effusions in various series depends on the geographical area, patient's age, and advances in the diagnostic methods and treatment of the underlying causes. The difficulty in determining the cause of pleural effusion is shown by the fact that in many series "unknown aetiology" constitutes nearly $15 \%$.

It is generally admitted that defining a pleural effusion as a transudate limits the differential diagnosis to a small number of disorders. It also ends the need for further diagnostic workup of the pleural effusion itself.

Very early criteria include pleural fluid (PF) specific gravity, cell counts and the presence or absence of clotting in the fluid. One of the first methods of differentiation was the pleural fluid protein level of $3 \mathrm{~g} / \mathrm{dl}$. Carr and Power found that $8 \%$ of exudates and $15 \%$ of transudates were misclassified by this criterion.

\section{CONCLUSION:}

The levels of pseudocholinesterase in pleural fluid and its fluid to serum ratio are significantly higher in exudative pleural effusions than transudative ones. These two are better parameters that can be used to differentiate between transudates and exudates. The ratio of pleural fluid to serum pseudocholinesterase ratio is superior to Light's criteria 
in differentiating between transudates and exudates.

\section{REFERENCES:}

1. Malyse ML. Non-Malignant Pleural Effusions. In: Fishman AP, Elias JA, Fishman JA, Grippi MA, Senior RM, Pack AI, editors. Fishman's Pulmonary Diseases and Disorders. $4^{\text {th }}$ ed. Vol 2. New York: McGraw Hill; 2008. p. 1487.

2. Light RW, McGregor MI, Luchsinger PC. "Pleural effusion: The diagnostic separation of transudates and exudates". Ann Intern Med 1972; 77:507-8

3. Light RW. Disorders of the pleura. In: Kasper DL, Fauci AS, Hauser SL, Longo DL, Jameson JL, Loscalzo J, editors. Harrison's principles of Internal Medicine. $19^{\text {th }}$ ed. Vol 2. New York: McGraw Hill; 2015.p. 1716.

4. Reechaipichitkul W, Kawamatawong T, Teerajetgul Y, Patjanasoontorn B. Diagnostic role of pleural fluid adenosine deaminase in tuberculous pleural effusion. Southeast Asian J Trop Med Public Health 2001;32:383-9.

5. Sharma SK, Suresh V, Mohan A, Kaur P, Saha P, Kumar A, Pande JN. A prospective study of sensitivity and specificity of adenosine deaminase estimation in the diagnosis of study of sensitivity and specificity of adenosine deaminase estimation in the
tuberculosis pleural effusion. Indian J Chest Dis Allied Sci 2001:43:149-55.

6. Gupta KB, Tandon S, Singh GP, Dhania OP, Jamneja AK. Pleural fluid cholesterol and serum cholesterol ratio as a parameter to differentiate between pleural transudate and exudate. Ind J Tub 1999;46:255-60.

7. Suay VG, Moragon EM, Viedma EC, Tordesa MP, Fabregas ML, Aldas JS. Pleural cholesterol in differentiating transudates and exudates. Respiration 1995;62:57-63.

8. Meisel S, Shamis A, Thaler M, Nussinovicht N, Rosenthal T. Pleural fluid to serum bilirubin concentration ratio for the separation of transudates from exudates. Chest 1990; 98: 141-4.

9. Paramothayan NS, Barron J. New criteria for the differentiation between transudates and exudates. Journal of Clinical Pathology. 2002;55(1):69-71.

10. Cabrer B Bofill D, Grau A. Valore de la colinesrasa en liquido plerual para su diagnostico etiolgico. Rev Clin Esp 1978; 150:183-4.

11. Garcia-Pachon E, Padilla-Navas I, Sanchez JF, Jimenez B, Custardoy J. Pleural fluid to serum cholinesterase ratio for the separation of transudates and exudates. Chest. 1996 Jul; 110(1):97-101

12. Ozer F, Kanat F, Kalem A, Imecik O.Diagnostic efficiency of pseudocholinesterase level in discrimination of transudates-exudates Tuberk Toraks. 2003;51(4):398-404

13. Sharma M, Gupta KB, Goyal KM, Nand N. Evaluation of cholinesterase to differentiate pleural exudates and transudates. J Assoc Physicians India. 2004 May; 52:387-90.

14. Naveen M, Vanitha S, Chowdareddy N. Comparison of Diagnostic Efficacy of Cholinesterase Levels to Differentiate Pleural Exudates and Transudates that of Lights Criteria. Sch J App Med Sci. 2014; 2(3C):1037-40 